\title{
Self-assessment and aggression's manifestation of judo wrestlers in age and qualification aspects
}

\author{
Ivaskiene V.P. ${ }^{1}$, Skyriene V.V. ${ }^{1}$, Markevičius V.Z. ${ }^{2}$ \\ ${ }^{1}$ Lithuanian Sports University, Kaunas, Lithuania \\ ${ }^{2}$ Mykolas Romeris University, Vilnius, Lithuania
}

\begin{abstract}
Purpose:

to determine self assessment and aggression's manifestations of judo wrestlers in age and qualification aspects.

Material: $\quad$ in the research boys - Judo wrestlers from sport schools of Kaunas (Lithuania) participated ( $\mathrm{n}=90$, age $16.9 \pm 2.0$ years). The athletes were divided into three groups. In qualification aspects were divided into two groups. The first group was composed as per sport achievements - the members of combined Lithuanian teams. The second group consisted athletes of different sport categories, which were not the members of combined teams. We used questionnaire as per scale of self assessment of $\mathrm{M}$. Rosenberg and questionnaire of aggressiveness of Buss-Perry. Estimation of the received data was fulfilled with the help of $U$ criterion of Manna-Whitney, $\mathrm{H}$ criterion of Kruskall-Wallis and X2-criterion. Assessment of confidence of mean group data's differences was fulfilled by Student's t-test. Correlations of indicators were determined with the help of correlation coefficient of Spearmen.

Results: $\quad$ with increasing of Judo wrestlers' age we observed the tendency to increasing of their self-assessment. The older sportsmen become the higher is theirs aggressiveness. Depending on self-assessment level we did not find statistically confident differences in their aggression indicators. Large quantity of elite Judo wrestlers has high self-assessment. Self assessment and aggression indicators of sportsmen with sport categories statistically do not differ for elite Judo wrestlers' indicators. Correlation between mean level of self assessment and aggression are present only in young Judo wrestlers.

Conclusions: in all age groups of Judo wrester's average level of self assessment prevails. Higher level is characteristic only for members of combined teams of the country. Judo wrestlers' aggression depending on age differs only by one component (more adult wrestlers are more aggressive than juniors). In respect to the level of sportsmanship - differences are absent.

Keywords: Judo, self-assessment, aggression, age group, sportsmanship.
\end{abstract}

\section{Introduction}

Self-assessment is one of the most important psychic structures, which control people's attitude towards themselves and events around them. It is the central component of personality and plays the role of activity's regulator. Self-assessment ensures the best adaptation to constantly varying life conditions. It facilitates achievement of high results in any activity $[2,3,26]$.

Self-assessment is defined as assessment of person's own physical and psychic qualities, behavior, achievements and failures, advantages and drawbacks, own potentials and abilities [1, 3, 8, 28].

Aggression is closely connected with sport activity. It is observed at all its levels - from junior to professional leagues [16]. Recent time, in scientific literature, different factors or reasons, facilitating unbearably aggressive adolescents' behavior, practicing sports, have been being analyzed. Competitions (contest), by its nature, imply impulses of aggression. But such aggression is determined by competition rules. It depends on many factors. Individual self-assessment is closely connected with the following: aggressive reactions; ability to control aggressive impulses; ability to manifest such energy in socially acceptable way. Self assessment is especially important in adolescent's age. In this age self cognition expands; new forms of self control appear. Self assessment is one of personality's qualities, influencing significantly (c) Ivaskiene V.P., Skyriene V.V., Markevičius V.Z., 2017 doi:10.15561/18189172.2017.0403 on individual understanding own self-sufficiency, interpersonal communication, demand in contest with surrounding people [20].

To larger extent aggressiveness is noticeable in athletes and physically active people [7, 21, 32]. Sports permit to express aggressive feelings. It does no harm to other people and forms constructive ways of sportsmen's aggressive behavior [7]. Aggression is characteristic for many kinds of sports [10, 22, 23]. As a phenomenon aggression is studied in different aspects. Endresen \& Olweus [15] stresses on influence of personalities' qualities on aggressiveness in sports. The authors affirm that expression of aggression in certain kind physical activity coincides with aggressiveness in everyday life. The authors note that earlier quite an opposite opinion existed: it was considered that sports practicing weakened behavior aggressiveness.

In sport activity the so-called instrumental aggressiveness is manifested most frequently: i.e. aggressiveness is used for achievement victory [24, 30, 34, $37]$. For victory in competition coaches create attacking strategy. Such aggressive strategies are most frequent in kinds of sports, where frequent and close physical contacts with opponent take place [12]. The distinctive feature of opponents' such contacts is tolerable perception of instrumental aggression. Often such strategy comes out of frames of permitted competition rules. This makes sports still more cruel and aggressive [33]. 
In some kinds of sports aggressive behavior is admitted and encouraged, for example in boxing and hockey. Though, it contradicts moral and social norms and rules. For achievement victory athletes are recommended to behave aggressively $[18,35]$.

The problem of aggressive behavior is regarded rather in detail in scientific literature. However there are still little works, devoted to self assessment and aggression of people, practicing sports (especially martial arts). That is why the object of the present research is study of interconnections of aggressions and self assessment of Judo wrestlers.

The hypothesis of the research was assumption that self-assessment and aggression of older and elite Judo wrestlers are higher than of younger sportsmen.

The purpose of the research is to determine self assessment and aggression's manifestations of Judo wrestlers in age and qualification aspects and to determine self assessment and aggression's manifestations of Judo wrestlers in age and qualification aspects.

\section{Material and methods}

Participants: in the research boys - Judo wrestlers from sport schools of Kaunas (Lithuania) participated $(n=90$, age $-16.9 \pm 2.0$ years). The athletes were divided into three groups. In qualification aspects were divided into two groups. The first group was composed as per sport achievements - the members of combined Lithuanian teams. The second group consisted athletes of different sport categories, which were not the members of combined teams (see table 1).

The athletes were selected by method of "convenient" sampling (coming from possibilities of questioning). Before questioning we received the consent for participation in the researches of: sportsmen, their parents, coaches and administrations of sport organizations.

Organization of the research: the research was fulfilled in 2015. We used anonymous questioning. For self assessment of the tested we used the scale of M. Rosenberg (The Rosenberg Self-Esteem Scale (SES, 1965). The scale consisted of 10 affirmations, characterizing human state. Sportsmen were to assess every affirmation, choosing one of four variants of answers: from "completely agree" to "flatly disagree". The sum of answers was estimated from 0 to 30 points. The highest was the sum of points the greater was self-assessment: less than 10 points meant low self-assessment; 11-20 points - average selfassessment and 21-30 points - high self-assessment [31] with indicator of internal reliability of scale Cronbach $\alpha$ $=0.78$.

For determination of aggression's kinds we used Personality questionnaire Buss-Perry Aggression Questionnaire (BPAQ, 1992. The questionnaire consists of 29 statements. It has the following sub-scales: physical and verbal aggression, anger and hostility [13] with indicator of internal reliability of scale Cronbach $\alpha=0.89$. Every statement of the scale was estimated from 1 (have no) to 7 (very typically) points. The more aggressiveness is expressed, the higher was the sum of points: physical aggressiveness - 9 statements; verbal aggression - 5 points; anger -7 statements and hostility -8 statements.

Statistical analysis: the received data were processed with the help of SPSS (Statistical Package for Social Science) 17.0 programs. The received data were estimated with the help of non parametrical criteria. Two independent samples were compared with MannWhitney U-test. More than two independent samples were compared with H- Kruskal-Wallis test [25]. Confidence of mean group data differences was found with Student's $\mathrm{t}$-test at significance level of $\mathrm{p}<0.05$. For comparison of self assessment levels of different groups' tested we used $\chi^{2}$ - criterion. критерий. Correlations of indicators were determined with the help of correlation coefficient of Spearmen.

\section{Results}

The fulfilled questioning permitted to find selfassessment and aggressiveness indicators of the respondents (see table 2). It was found that the highest self assessment was intrinsic to older sportsmen (juniors) and reaches $20.56 \pm 3.52$ points. Self assessment of younger athletes does not differ statistically $(p>0.05)$ though it is a little lower.

Physical and verbal aggression, as well as anger are not influenced by age of Judo-wrestlers (see table 2) $(\mathrm{p}>0.05)$. However, the older Judo wrestlers become the higher their hostility rises statistically $(\mathrm{p}<0.05)$.

Most of all age groups' sportsmen have average selfassessment: youngsters $-73.1 \%$, cadets $-64.0 \%$, juniors - 59.0\%. With increasing athletes' age the tendency to their self-assessment rising is observed ( $p>0.05$ ) (fig.1).

We have not found statistical differences between aggression indicators depending on respondents' self assessment $(\mathrm{p}>0.05)$ : i.e. all forms of aggression are distributed uniformly (see table 3 ).

Average self-assessment of combined teams' members

Table 1. Characteristics of athletes

\begin{tabular}{llll}
\hline Groups & Age (years) & $\begin{array}{l}\text { The quantity of respondents } \\
\text { (n) }\end{array}$ & $\begin{array}{l}\text { The quantity of respondents } \\
\text { (\%) }\end{array}$ \\
\hline Boys (U-16) & $14-15$ & 26 & 28.9 \\
Cadets (U-18) & $16-17$ & 25 & 27.8 \\
Juniors (U-21) & $18-20$ & 39 & 43.3 \\
Elite sportsmen & $14-20$ & 29 & 32.2 \\
Sportsmen with sport categories & $14-20$ & 61 & 67.8 \\
\hline
\end{tabular}


Table 2. Self assessment and aggressiveness indicators in different age groups (points)

\begin{tabular}{|c|c|c|c|c|c|}
\hline Indicators & Group & $\bar{x}$ & SD & $\mathrm{H}$-criterion & $p=$ \\
\hline & Youngsters & 19.38 & 2.90 & & \\
\hline \multirow[t]{3}{*}{ Self assessment } & Cadet & 19.08 & 3.35 & 2.833 & 0.243 \\
\hline & Juniors & 20.56 & 3.52 & & \\
\hline & Youngsters & 36.50 & 7.23 & & \\
\hline \multirow[t]{3}{*}{ Physical aggression } & Cadet & 34.08 & 5.45 & 0.878 & 0.645 \\
\hline & Juniors & 34.77 & 4.59 & & \\
\hline & Youngsters & 20.04 & 4.39 & & \\
\hline \multirow[t]{3}{*}{ Verbal aggression } & Cadet & 19.72 & 3.69 & 3.610 & 0.164 \\
\hline & Juniors & 17.92 & 4.01 & & \\
\hline & Youngsters & 28.69 & 5.41 & & \\
\hline \multirow[t]{3}{*}{ Anger } & Cadet & 27.68 & 4.31 & 1.210 & 0.546 \\
\hline & Juniors & 27.23 & 3.77 & & \\
\hline & Youngsters & 28.96 & 5.86 & & \\
\hline \multirow[t]{2}{*}{ Hostility } & Cadet & 29.84 & 5.01 & 6.135 & 0.047 \\
\hline & Juniors & 32.79 & 6.74 & & \\
\hline
\end{tabular}

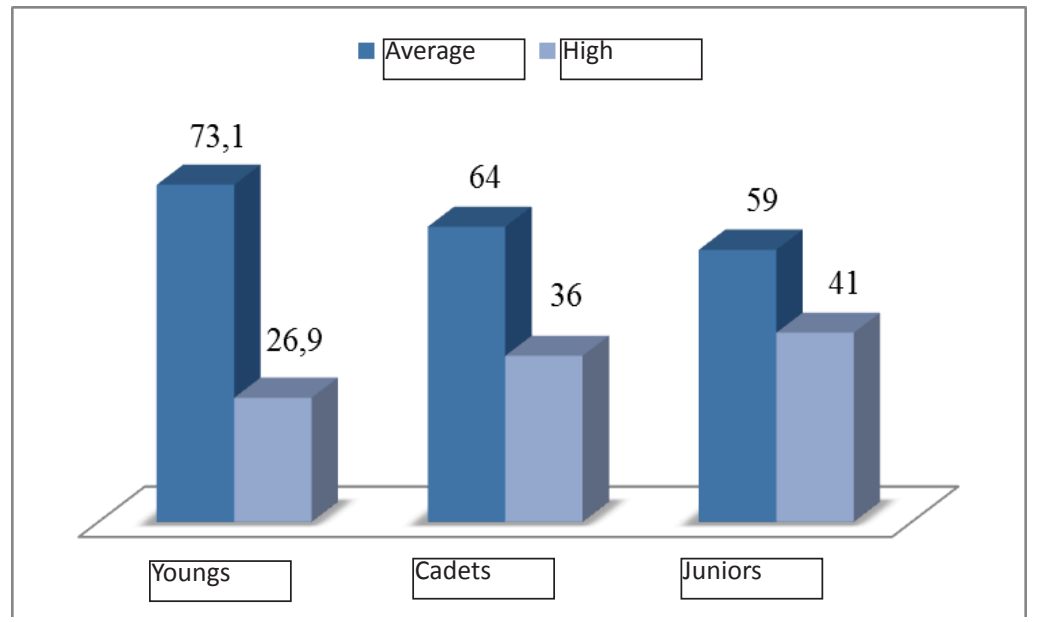

Fig. 1. Self assessment of different age Judo wrestlers (\%). $\left(\chi^{2}(2)=1.357 ; p>0.05\right)$

is $20.52 \pm 3.66$ points; physical aggression reaches 37.34 \pm 7.07 , verbal $-19.48 \pm 5.38$ and anger $-28.79 \pm 5.12$; hostility is $-32.28 \pm 5.36$ points (see table 4 ). Indicators of sportsmen's with sport categories self assessment and aggression statistically do not differ from the same of elite athletes $(\mathrm{p}>0.5)$.

Analysis of self-assessment data, depending on athletes' sportsmanship showed that no one of them had low self assessment level (see table 5). But high self assessment level have confidently greater quantity of combined teams' members than athletes with sport categories $(\mathrm{p}<0.05)$.

No correlations were found between self assessment and aggression's kinds of cadets and juniors. For youngsters we found average level correlation between self assessment and physical aggression (see table 6).

\section{Discussion}

The problem of correlations between self assessment and aggression in sports has being always existed. Till nowadays different contradictory hypothesis has been formulated. In these polemic martial arts, popular among athletes of different age, take special place.

The hypothesis, formulated by us, was proved partially. Athletes'self assessment in respect to their age statistically does not differ, but it differs depending on sportsmanship (higher self assessment is characteristic for combined teams' members). Judo wrestlers' aggression, depending on age, differs only by one component (hostility), while depending on sportsmanship differences are absent.

It was found that manifestations of anger, physical and verbal aggressions of different age Judo wrestlers are nearly the same $(p>0.05)$, while manifestation of hostility is different. More adult athletes have confidently greater hostility $(p<0.05)$. The level of sport qualification practically does not influence oh Judo wrestlers' aggression.

The received by us results partially coincide with results of other work [36]. This author found that there is the tendency of self assessment and aggression rising in adolescents, depending on improvement of their sport results.

In other study it was determined that self assessment 
Table 3. Aggression indicators depending on self assessment of the tested (points)

\begin{tabular}{|c|c|c|c|c|c|c|}
\hline Kinds of aggression & $\begin{array}{l}\text { Self-assessment } \\
\text { level }\end{array}$ & $\mathbf{n}$ & $\overline{\mathbf{x}}$ & SD & U-criterion & $p=$ \\
\hline \multirow{2}{*}{ Physical } & Average & 58 & 34.45 & 4.37 & \multirow{2}{*}{818.5} & \multirow{2}{*}{0.354} \\
\hline & High & 32 & 36.22 & 7.51 & & \\
\hline \multirow{2}{*}{ Verbal } & Average & 58 & 19.05 & 3.87 & \multirow{2}{*}{834.5} & \multirow{2}{*}{0.429} \\
\hline & High & 32 & 19.00 & 4.59 & & \\
\hline \multirow{2}{*}{ Anger } & Average & 58 & 27.48 & 3.62 & \multirow{2}{*}{925.5} & \multirow{2}{*}{0.983} \\
\hline & High & 32 & 28.31 & 5.64 & & \\
\hline \multirow{2}{*}{ Hostility } & Average & 58 & 30.79 & 6.84 & \multirow{2}{*}{893.0} & \multirow{2}{*}{0.767} \\
\hline & High & 32 & 31.00 & 5.04 & & \\
\hline
\end{tabular}

Table 4. Aggression and self assessment indicators depending on sportsmanship of the tested (points)

\begin{tabular}{|c|c|c|c|c|c|c|}
\hline Indicators & Group & $\mathbf{n}$ & $\overline{\mathbf{x}}$ & SD & U-criterion & $p=$ \\
\hline \multirow{2}{*}{ Physical aggression } & 1 & 29 & 20,52 & 3,66 & \multirow{2}{*}{739,0} & \multirow{2}{*}{0,206} \\
\hline & II & 61 & 19,48 & 3,15 & & \\
\hline \multirow{2}{*}{ Verbal aggression } & I & 29 & 37,34 & 7,07 & \multirow{2}{*}{670,5} & \multirow{2}{*}{0,064} \\
\hline & II & 61 & 34,00 & 4,62 & & \\
\hline \multirow{2}{*}{ Anger } & I & 29 & 19,48 & 5,38 & \multirow{2}{*}{823,5} & \multirow{2}{*}{0,597} \\
\hline & ॥ & 61 & 18,82 & 3,38 & & \\
\hline \multirow{4}{*}{ Hostility } & 1 & 29 & 28,79 & 5,12 & \multirow{2}{*}{735,5} & \multirow{2}{*}{0,197} \\
\hline & II & 61 & 27,30 & 4,03 & & \\
\hline & I & 29 & 32,28 & 5,36 & \multirow{2}{*}{697,0} & \multirow{2}{*}{0,104} \\
\hline & II & 61 & 30,20 & 6,54 & & \\
\hline
\end{tabular}

Notes: I group - elite sportsmen; II group - sportsmen with sport categories.

Table 5. self-assessment of different sportsmanship athletes

\begin{tabular}{llllll}
\hline \multirow{2}{*}{ Self assessment } & \multicolumn{2}{l}{$\begin{array}{l}\text { Members of combined } \\
\text { teams of Lithuania }\end{array}$} & $\begin{array}{l}\text { Sportsmen with sport } \\
\text { categories }\end{array}$ & Statistical indicators \\
& $\mathbf{n}$ & $\mathbf{\%}$ & $\mathbf{n}$ & $\mathbf{\%}$ & \\
\hline Low & 0 & 0.0 & 0 & 0.0 & $\chi^{2}(1)=4.882$ \\
Average & 14 & 48.3 & 44 & 72.1 & $p=0.027$ \\
High & 15 & 51.7 & 17 & 27.9 & \\
\hline
\end{tabular}

Table 6. Correlations between self assessment and aggression's kinds in Judo wrestlers- youngsters ( $r$ )

\begin{tabular}{lllll}
\hline Indicators & $\mathbf{2}$ & $\mathbf{3}$ & $\mathbf{4}$ & $\mathbf{5}$ \\
\hline 1 & $\mathbf{0 . 5 2 0}$ & 0.364 & -0.065 & 0.136 \\
2 & & 0.339 & 0.318 & -0.302 \\
3 & & -0.118 & -0.250 \\
4 & & & 0.118 \\
\hline
\end{tabular}

Indicators: 1 - self assessment; 2 - physical aggression; 3 - verbal aggression; 4 - anger; 5 -hostility.

of young rugby players is lower than the same of older athletes [37]. For the tested by us Judo wrestlers it is not characteristic. The tested by us athletes had average self-assessment level. It coincides with other data [4]. The authors found certain reduction of self assessment of athletes with sport categories in conditions of competitions [4]. It was found that adolescents, practicing sports, have higher self assessment [17].

It was also found that self assessment of elite athletes in different kinds of sports is confidently higher, comparing with athletes of lower qualification $[5,8,11]$. In opinion of a number of scientists [6], the most efficient are athletes with high self-assessment [2, 3].

Comparing with the tested by us athletes the boys from Lithuanian sport schools have higher self-assessment: high level - 56\% and low - y 18\% [27]. In our case high self assessment is characteristic for $51.7 \%$ members of Judo combined teams of Lithuania and for $27.9 \%$ of 
athletes with sport categories.

In opinion of some researchers [19, 20], just low selfassessment is a risk factor of aggression's emersion. In our study we did not register low self-assessment.

According to other work, on initial stages of martial arts' training aggression is connected with the following: sport results; victory on competitions; with intransigence to drawbacks; with strive for self-affirmation at the account of other people [9]. Experience of martial arts training causes reduction of aggression. Some changes in personality's vaules take plac. It conditiones shift of value orientation from practical result to the training process itself [9].

We did not find any correlations between selfassessment and aggression's manifestations of Judojuniors and cadets. In Judo youngsters we found average level correlation between self-assessment and physical aggression: the higher self assessment is, the more expressed is physical aggression.

In a number of works correlation of other kind was found: in adult rugby players there is no connection between self assessment and total indicator of aggression. In younger rugby players there is negative correlation: the lower self assessment is, the greater is total indicator of aggression [37].

In martial arts such forms of aggression can exist: instrumental, hostility or unfriendly behavior [35]. Instrumental aggression is motivated by strive for achievement of target. Such behavior looks like as previously planned for achievement of certain strategic advantage in fight. Martial arts athletes plan their tactic and fighting technique beforehand. Technical and tactical training directed at victory is the basis of all martial arts. It means that athlete shall traumatize his opponent or fulfill other aggressive actions for obtaining certain advantage or to win.
Rather often sport activity pre-conditions negative behavior. Unfortunately, coaches and spectators often encourage such athlete's behavior and explain it by need in formation sport character. Dunn et al. affirm that since early childhood it is necessary to cultivate negative attitude to aggression, to humiliation of human dignity. It is necessary to cultivate the idea that such behavior is not and cannot be the norm of life [14].

Endresen \& Olweus found that for athletes with bent to aggression (martial arts and power kinds of sports) destructive behavior even out of gym is characteristic [15]. There is an opinion that too high self assessment is connected with non adaptive manifestations of aggressiveness [29].

The prospects of the research imply working out of practical recommendations on formation of adequate self-assessment of Judo wrestlers and regulation of their aggressiveness by them.

\section{Conclusions:}

In all Judo wrestlers' age groups average selfassessment prevails. Higher self assessment is characteristic for members of Lithuanian combined teams $(p<0.05)$. Depending on age Judo wrestlers' aggression differs only by one component (youngsters are more hostile than juniors and cadets). Depending on sportsmanship, there are no differences.

\section{Acknowledgements}

We acknowledge Judo coach Inga Taujanskiene for assistance in our research.

\section{Conflict of interests}

The authors declare that there is no conflict of interests.

\section{References:}

1. Anan'ev BG. Man as an object of cognition, Sankt Petersburg: Peter; 2001. (in Russian)

2. Volkov DN, Krylov AA, Loviagina AE. On the probleem of sport abilities' self assessment. Teoriia i praktika fizicheskoj kul'tury, 2008;2:30-33. (in Russian)

3. Volkov DN. Correspondence of self assessment and coach's assessment of different successfulness sportsmen. Psikhologicheskie problemy samorealizacii lichnosti, 2010;13:34-40. (in Russian)

4. Gant EE, Sigal NS, Shtykh VA. Personality‘s qualities of sportsmen, practicing oriental martial arts. Slobozhans'kij naukovo-sportivnij visnik, 2013;1(34):91-94. (in Russian)

5. Zhilin SV. Perculiar aspects of sportsmen's Self-conception. Cand. Diss., Sankt Petersburg; 2003. (in Russian)

6. Zagajnov RM. The curse of profession: being and consciousness of practical psychologist. Moscow; 2001. (in Russian)

7. Il'in EP. Psychology of communication and interpersonal relations. Sankt Petersburg: Peter; 2009. (in Russian)

8. Lozovaia GV. Methodological problems of studying person's self-assessment. Ezhegodnik Rossijskogo psikhologicheskogo obshchestva, 2003;5:67-70. (in Russian)
9. Petrygin SB. Aggression of adolescents, practicing contact martial arts. Vestnik Riazanskogo gosudarstvennogo universiteta, 2012;4(37):23-35. (in Russian)

10.Stoliarov VI. The problems of modern sports ' humanization and ways for their solution. Sport values and ways of its humsnization. Moscow: Russian Academy of Education, Humanitarian Center "SpArt"RSAPC; 1996. (in Russian)

11. Strekalovskaia IN. Sportsmen's self assessment and its correction by means of self-cognition. Cand. Diss. Sankt Petersburg; 2005. (in Russian)

12.Bjorkqvist K. Sex differences in physical, verbal, and indirect aggression: A review of recent research. Sex Roles. A Journal of Research, 1994; 30:177-188.

13.Buss AH, Perry MP. The aggression questionnaire. Journal of Personality and Social Psychology, 1992; 63:452-459.

14.Dunn CJ, Dunn JGH, Bayduza A. Perceived athletic competence, sociometric status, and loneliness in elementary school children. Journal of Sport Behavior, 2008; 30(3):249269.

15.Endresen IM, Olweus D. Participation in power sports and antisocial involvement in preadolescent and adolescent boys. Journal of Child Psychology Psychiatry, 2005; 46(5):468478. 
16.Fields SK, Collins CL, Comstock RD. Conflict on the courts. A review of sports-related violence literature. Trauma, Violence Abuse, 2007; 8(4):359-369.

17.Findlay LC, Coplan RJ. Come out and play: Shyness in childhood and benefits of organized sports participation. Canadian Journal of Behavioral Science, 2008; 40(3):153161.

18.Gaskov AV, Kuzmin VA, Kudryavtsev DM, Iermakov SS. Successfulness of general and special physical qualities' development on different stage of students-boxers' training. Physical Education of Students. 2016;20(1):4-11. doi:10.15561/20755279.2016.0101

19.Heimpel S, Wood JV, Marshall MA, Brown JD. Do people with low self-esteem really want to feel better? Self-esteem differences in motivation to repair negative moods. Journal of Personality and Social Psychology, 2002; 82(1):128-147.

20.Hubbard DH. Should we be targeting self-esteem in treatment for offenders: Do gender and race matter in whether selfesteem matters? Journal of Offender Rehabilitation, 2006; 44(1):39-57.

21.Ivaškienè $\mathrm{V}$, Markevičius $\mathrm{V}$, Juknevičius $\mathrm{V}$, Velička $\mathrm{D}$. Different physical activity of senior adolescents, expressed in aggression and gender characteristics. Sporto mokslas, 2015; 1(79):52-56. (in Lithuanian)

22.Kalina RM, Jagiello W, Chodala A. The result of "testing fights in a vertical posture" as a criterion of talent for combat sports and self-defence - secondary validation (part I: the reliability). Archives of Budo Science of Martial Arts and Extreme Sports. 2015;11:229-38.

23.Klimczak J, Kalina RM, Jagiello W. Fun forms of martial arts in diagnosing and reducing aggressiveness - mental effects of a one-day course for Polish animators of sport. Health and Martial Arts in Interdisciplinary Approach. 2015:187-9.

24.Krenn B. The Effect of Uniform Color on Judging Athletes' Aggressiveness, Fairness, and Chance of Winning. Journal of Sport \& Exercise Psychology. 2015;37(2):207-12.

25.Kruskal WH, Wallis WA. Use of ranks in one-criterion variance analysis. Journal of the American Statistical Association, 1952; 47(260):583-621.
26.Kudryavtsev MD, Kramida IE, Iermakov SS, Osipov AY. Development dynamic of healthy life style personality component in relatively healthy students. Physical Education of Students. 2016;20(6):26-33. doi:10.15561/20755279.2016.0603

27.Masiliauskas D. Different physical exercises in adolescents' self-assessment. Socialiniai mokslai. Jaunuju mokslininku darbai, 2009; 2(23):162-166. (in Lithuanian)

28.Nideffer RM, Sagal MS. Assessment in Sport Psychology. Morgantown, WV: Fitness Information Technology; 2001.

29.Perez M, Vohs KD, Joiner TE. Discrepancies between selfand other- esteem as correlates of aggression. Journal of Social and Clinical Psychology, 2005; 24(5):607-620.

30.Ring C, Kavussanu M, Willoughby A. Pain thresholds, pain-induced frontal alpha activity and pain-related evoked potentials are associated with antisocial behavior and aggressiveness in athletes. Psychology of Sport and Exercise. 2016;22:303-11.

31.Rosenberg M. Society and the adolescent self-image. Princeton, NJ: Princeton University Press; 1965.

32.Stanger N, Kavussanu M, Ring C. Gender Moderates the Relationship Between Empathy and Aggressiveness in Sport: The Mediating Role of Anger. Journal of Applied Sport Psychology. 2017;29(1):44-58.

33. Stornes T, Roland E. Handball and aggression: An investigation of adolescent handball players' perceptions of aggressive behavior. European Journal of Sport Science, 2004; 4(1):68-74.

34.Šukys S. Factors of aggressiveness in sports. Ugdymas. Kūno kultūra. Sportas, 2003; 4(49):70-79. (in Lithuanian)

35.Šukys S. Social and ethical aspects of sports, Kaunas: LKKA, 2005. (in Lithuanian)

36. Tilindienè I. Sport measures in formation of relations with teenagers. Doctoral dissertation. Kaunas: LKKA, 2000. (in Lithuanian)

37.Zajančkauskaitè-Staskevičienè L, Milerytė A. Selfassessment and interface of employees. Ugdymas. Küno kultūra. Sportas, 2010; 3(78):113-119. (in Lithuanian)

Information about the authors:

Ivaskiene V.P.; http://orcid.org/0000-0002-1865-0226; vida.ivaskiene@Isu.It; Lithuanian Sports University; Sporto str. 6, LT-44221 Kaunas, Lithuania.

Skyriene V.V.; http://orcid.org/0000-0001-5360-4519; valentina.skyriene@lsu.It; Lithuanian Sports University; Sporto str. 6, LT-44221 Kaunas, Lithuania.

Markevičius V.Z.; http://orcid.org/0000-0002-5999-6549; markevicius@mruni.eu; Mykolas Romeris University; Ateities str. 20, LT08303 Vilnius, Lithuania.

Cite this article as: Ivaskiene V.P., Skyriene V.V., Markevičius V.Z. Self-assessment and aggression's manifestation of Judo wrestlers in age and qualification aspects. Pedagogics, psychology, medical-biological problems of physical training and sports, 2017;21(4):163-168. doi:10.15561/18189172.2017.0403

The electronic version of this article is the complete one and can be found online at: http://www.sportpedagogy.org.ua/index.php/PPS/issue/archive

This is an Open Access article distributed under the terms of the Creative Commons Attribution License, which permits unrestricted use, distribution, and reproduction in any medium, provided the original work is properly cited (http://creativecommons.org/licenses/by/4.0/deed.en).

Received: 31.03.2017

Accepted: 12.04.2017; Published: 30.08 .2017 